\title{
Water temperature, body mass and fasting heat production of pacu (Piaractus mesopotamicus)
}

\author{
FREDY A.A. AGUILAR ${ }^{1}$, THALINE M.P. DA CRUZ ${ }^{1}$, GERSON B. MOURÃO ${ }^{2}$ and JOSÉ EURICO P. CYRINO ${ }^{3}$ \\ ${ }^{1}$ Programa de Pós-Graduação em Ciência Animal e Pastagens, Escola Superior de Agricultura "Luiz de \\ Queiroz”, Universidade de São Paulo, Av. Pádua Dias, 11, 13418-900 Piracicaba, SP, Brazil \\ ${ }^{2}$ Departamento de Zootecnia, Escola Superior de Agricultura “Luiz de Queiroz", Universidade \\ de São Paulo, Av. Pádua Dias, 11, 13418-900 Piracicaba, SP, Brazil \\ ${ }^{3}$ Setor de Piscicultura, Departamento de Zootecnia, Escola Superior de Agricultura "Luiz de Queiroz", \\ Universidade de São Paulo, Av. Pádua Dias, 11, 13418-900 Piracicaba, SP, Brazil
}

Manuscript received on September 27, 2016; accepted for publication on January 9, 2017

\begin{abstract}
Knowledge on fasting heat production $\left(\mathrm{HE}_{\mathrm{f}}\right)$ of fish is key to develop bioenergetics models thus improving feeding management of farmed species. The core of knowledge on $\mathrm{HE}_{\mathrm{f}}$ of farmed, neotropical fish is scarce. This study assessed the effect of body mass and water temperature on standard metabolism and fasting heat production of pacu, Piaractus mesopotamicus, an omnivore, Neotropical fresh water characin important for farming and fisheries industries all through South American continent. An automated, intermittent flow respirometry system was used to measure standard metabolic rate (SMR) of pacu $(17-1,050 \mathrm{~g})$ at five water temperatures: 19, 23, 26, 29 and $33{ }^{\circ} \mathrm{C}$. Mass specific SMR increased with increasing water temperature but decreased as function of body mass. The allometric exponent for scaling $\mathrm{HE}_{\mathrm{f}}$ was 0.788 , and lied in the range recorded for all studied warm-water fish. The recorded van't Hoff factor $\left(\mathrm{Q}_{10}\right)$ for pacu (2.06) shows the species low response to temperature increases. The model $\mathrm{HE}_{\mathrm{f}}=0.04643 \times \mathrm{W}^{0.7882} \times \mathrm{T}^{1.837}$ allows to predict $\mathrm{HE}_{\mathrm{f}}\left(\mathrm{kJ} \mathrm{d}^{-1}\right)$ from body mass $(\mathrm{W}, \mathrm{kg})$ and water temperature $\left(\mathrm{T},{ }^{\circ} \mathrm{C}\right)$, and can be used in bioenergetical models for the species.
\end{abstract}

Key words: allometric exponent, bioenergetics models, pacu, respirometry, standard metabolic rate.

\section{INTRODUCTION}

Pacu Piaractus mesopotamicus (Holmberg 1887) is an omnivore, Neotropical fresh water characin, of great commercial value for fisheries and aquaculture in many South American countries. This species naturally dwells in riverine environments with temperature ranging on 15 to $35^{\circ} \mathrm{C}$, but the optimal

Correspondence to: José Eurico Possebon Cyrino

E-mail: jepcyrino@usp.br range for farming the species lies within 20 and 28 ${ }^{\circ} \mathrm{C}$ (Milstein et al. 2000).

Knowledge on standard metabolism and fasting heat production (heat loss by animals in a post absorptive state $-\mathrm{HE}_{\mathrm{f}}$ ) of pacu is scarce but necessary, particularly for the development of bioenergetics models of farmed fish feeding on processed feeds, given that heat loss regulate feed intake by fish (NRC 2011, Houlihan et al. 2001). In addition, larger animals ordinarily require more 
oxygen and cellular fuel than smaller animals for respiratory process; however, this relationship is usually non-linear. The allometric equation $a x^{b}$, where ' $a$ ' is a constant, ' $x$ ' is the body weight and ' $b$ ' is the metabolic body mass exponent (Clarke and Johnston 1999, Glencross and Felsing 2006), is used for studying this non-linear relationship. Clarke and Johnston (1999) found an average value for exponent $b=0.79$, but also pointed out that scaling exponent vary in association with evolutionary and statistical biases.

Temperature obviously affects standard metabolism of ectothermic animals as fishes, but the intensity of the effect is species-specifics and vary widely. The basal metabolism of fish normally increases as water temperature raises towards the lethal limit, and conforms to van't Hoff's factor, which is: A rise in temperature of about $10{ }^{\circ} \mathrm{C}$ raises the speed of reaction by a factor of two to three $\left(\mathrm{Q}_{10}=2-3\right)$ (Steffens 1989), an average $\mathrm{Q}_{10}=2.4$ acknowledged for several fish (Clarke and Johnston 1999). The objective of this study was to assess the effect of body mass and water temperature on the $\mathrm{HE}_{\mathrm{f}}$ of pacu adding novel information to the development of bioenergetics models for the species.

\section{MATERIALS AND METHODS}

\section{RESPIROMETRY SYSTEM}

Oxygen consumption of 103 pacus was measured at five water temperatures $19(n=19), 23(n=24)$, $26(n=26), 29(n=21)$ and $33{ }^{\circ} \mathrm{C}(n=13)$, i.e., 103 independent observations were recorded. Temperature range followed local geographical and climate classification as provided in http:// www.cpa.unicamp.br/outras-informacoes/clima muni_436.html: Piracicaba, SP, Brazil; 22 43'31" S, 47³8'57" W; altitude $547 \mathrm{~m}$; Koeppen's Cwa climate. The fish weight ranged from 17 to $1,050 \mathrm{~g}$. The trials were set up under computercontrolled conditions, with the aid of an automated, intermittent flow respirometry system (DAQPAC-F1; AutoResp software, Version 2.2.0; Loligo Systems, Tjele, Denmark), respiratory chambers (4.087, 6.042, 14.634, 46.953 L) suitable to varying fish body size and mass (Steffensen et al.1984, Herrmann and Enders 2000). Oxygen levels in the respirometer were recorded by a Fibox 3 fiber optic oxygen meter (PreSens, Regensburg, Germany). Measurement cycle (flux-wait-measurement) was adapted to fit chamber volume, fish body mass and temperature. Flux period was adapted to restore the oxygen concentration after measurement period and measurement interval was adapted to ensure that the linear decline in oxygen content was underway. Measurement period was fitted to yield linear regression equations (oxygen concentration vs time), $\mathrm{r}^{2} \approx 0.95$ (Svendsen et al. 2016).

\section{EXPERIMENTAL PROCEDURES, DATA ANALYSIS AND MODELLING}

After fasting for 48 hours to circumvent peak oxygen consumption rates resulting from specific dynamic action, fish were sedated (benzocaine; $50 \mathrm{mg}$ $\mathrm{L}^{-1}$ ), weighted and stocked into the respirometry chamber late afternoon, and respiratory data $\left(\mathrm{MO}_{2}\right)$ were continuously, automatically sampled overnight. Respirometry chambers and tubing were cleaned using a sponge before starting each assay to reduce microbial interference in $\mathrm{MO}_{2}$, and microbial oxygen consumption of the system was measured at the end of each assay and subtracted from registered measurements of fish consumption to circumvent measurement biases. Trials were set up indoor, in an isolated room, holding tanks (500 L) supplied by closed loop water circulation system, 12-h light : 12-h dark photoperiod, "light of day" halogen lamps (Heinen 1998). Trials were carried out under Protocols CEUA-ESALQ-USP \# 2014-01 and 2014-13. 


\section{STANDARD METABOLIC RATE}

The mass-specific, standard metabolic rate (SMR) was calculated according to Hölker (2003), as follows:

$$
\operatorname{SMR}\left(\mathrm{mg} \mathrm{kg}^{-1} \mathrm{~h}^{-1}\right)=[\mathrm{Vx}(\mathrm{Bt}-\mathrm{Bm})] / \mathrm{M}
$$

where $\mathrm{Bt}=$ total respiration $\left(\mathrm{mg} \mathrm{O}_{2} \mathrm{~L}^{-1} \mathrm{~h}^{-1}\right)$, is the average of three lowest $\mathrm{MO}_{2}$ measurements in the stabilization phase of each assay (Roche et al. 2013) after atypical, very low measurements (outliers) were excluded from further data processing (Herrmann and Enders 2000) and measurements with $r^{2}<0.9$ were also excluded (Hölker 2003); Bm $=$ microbial respiration $\left(\mathrm{mg} \mathrm{O}_{2} \mathrm{~L}^{-1} \mathrm{~h}^{-1}\right)$, is the average of five stable and representative measurements after fish were removed from the respirometry chamber; $\mathrm{V}=$ respirometric volume $(\mathrm{L})$, calculates as chamber volume plus tubing volume minus fish volume (fish density supposed as $1 \mathrm{~g} \mathrm{ml}^{-1}$ ); $\mathrm{W}=$ body mass $(\mathrm{kg})$ of fish.

Modelling of mass-specific SMR ( $\mathrm{mg} \mathrm{kg}^{-1}$ $\left.\mathrm{h}^{-1}\right)$ considered the respiration function, which is: $\mathrm{SMR}=\mathrm{RA} \times \mathrm{M}^{\mathrm{RB}} \times \mathrm{e}^{(\mathrm{RQ} \times T)}$, where $R A$ is the intercept of the allometric mass function $\left(\mathrm{mg} \mathrm{kg}^{-1} \mathrm{~h}^{-1}\right), M$ is the body mass $(\mathrm{g}) ; R B$ is the slope of the allometric mass function; $R Q$ is the exponential coefficient for the temperature-dependence function, and $T$ is water temperature $\left({ }^{\circ} \mathrm{C}\right)$ (Mesa et al. 2013).

\section{FASTING HEAT PRODUCTION AT REST CONDITION}

The oxy-calorific coefficient for fat oxidation (13.72 $\mathrm{J} \mathrm{mg} \mathrm{O}_{2}^{-1}$ ) was used to convert SMR to $\mathrm{HE}_{\mathrm{f}}$ (Elliott and Davidson 1975). For modeling $\mathrm{HE}_{\mathrm{f}}\left(\mathrm{kj} \mathrm{d}^{-1}\right)$ as function of body mass $(\mathrm{W}, \mathrm{kg})$ and temperature $\left(\mathrm{T},{ }^{\circ} \mathrm{C}\right)$, a function $\mathrm{HE}_{\mathrm{f}}=\mathrm{a} \times \mathrm{M}^{\mathrm{b}} \times \mathrm{T}^{\mathrm{c}}$ was fitted, where ' $a$ ' is $\mathrm{HE}_{\mathrm{f}}$ when $\mathrm{M}=1$ and $\mathrm{T}=1$, ' $\mathrm{b}$ ' is the allometric exponent for scalling $\mathrm{HE}_{\mathrm{f}}$, and ' $\mathrm{c}$ ' is an exponent for temperature effect on $\mathrm{HE}_{\mathrm{f}}$ Because of heterocedasticity detected in the initial model (minimizing the sum of squared residuals), two weighting schemes for model residuals (1/Y and 1/
$\mathrm{Y}^{2}$ ) were done to yield unbiased estimators (Bonate 2011). The models were fitted using the NLRWR package in R 3.0.3 (Ritz and Streibig 2008).

Mean square error of prediction (MSEP) was used to test the accuracy of model $\mathrm{HE}_{\mathrm{f}}$ predictions, as follows:

$$
\text { MSPE }=\sum_{i=1}^{n}\left(O_{i}-P_{i}\right)^{2} / n
$$

in which: $\mathrm{O}_{i}$ is the $\mathrm{i}^{\text {th }}$ registered values; $\mathrm{P}_{\mathrm{i}}$ is the $\mathrm{i}^{\text {th }}$ predicted values, and $\mathrm{n}$ is the number of observations. The MSEP was decomposed into components resulting from overall bias of prediction, deviation of the regression slope from unity, and random variation around the regression line (Bibby and Toutenburg 1977). The coefficient of model determination (CD) was also considered for assessing the adequacy of the models (Loague and Green 1991):

$$
C D=\sum_{i=1}^{n}\left(O_{i}-\bar{o}\right)^{2} / \sum_{i=1}^{n}\left(P_{i}-\bar{o}\right)^{2}
$$

where $\mathrm{O}_{i}$ is the $i^{\text {th }}$ observed values; $\mathrm{P}_{i}$ is the $i^{\text {th }}$ predicted values; $n$ is the number of observations, and is average of registered values.

\section{METABOLIC INDICES}

The Arrhenius model was fitted to recorded data and the slope was used to determine the apparent energy activation (Ea) of SMR increases (Pirozzi and Booth 2009), as follows:

$$
\mathrm{Ea}=- \text { slope }^{\mathrm{x}} \mathrm{R}
$$

in which 'slope' is the slope of the linear regression of SMR $\left[\ln \left(\mathrm{mgO}_{2} \mathrm{~kg}^{-0.8} \mathrm{~h}^{-1}\right)\right]$ on the inverse of temperature in Kelvin degrees $\left(\mathrm{K}^{-1 *} 10^{3}\right)$ and $\mathrm{R}$ is the universal gas constant $\left(8.3145 \times 10^{-3} \mathrm{~J} \mathrm{~mol}^{-1}\right.$ $\mathrm{K}^{-1}$ ). To assess the sensibility of pacu's $\mathrm{HE}_{\mathrm{f}}$ to temperature increases, the $\mathrm{Q}_{10}$ value was calculated using the predicted $\mathrm{HE}_{\mathrm{f}}$ for $1.0 \mathrm{~kg}$ fish, as follows: 


$$
\mathrm{Q}_{10}=\left(\mathrm{HE}_{\mathrm{f} 2} / \mathrm{HE}_{\mathrm{f} 1}\right)^{(10 /(12-\mathrm{t})}
$$

were: $\mathrm{HE}_{\mathrm{f} 1}$ and $\mathrm{HE}_{\mathrm{f} 2}$ are the fasting heat production at temperatures $t_{1}$ and $t_{2}$, respectively (Glencross and Felsing 2006).

\section{RESULTS}

\section{STANDARD METABOLIC RATE}

Mass-specific SMR increased with water temperature but decreased as function of body mass (Fig. 1). The fitted model and all parameter coefficients of model were significant $(t$-tests: $\mathrm{p}<$ 0.0001).

\section{FASTING HEAT PRODUCTION AT REST CONDITION}

All models showed similar prediction capacity (similar MSEP), random errors being the main source of error. The model fitted by the $1 / \mathrm{Y}^{2}$ weighting scheme yielded the lowest standard error for parameter ' $b$ ', with $C D \approx 1$, indicating that the variation of predicted values around the recorded mean was the most similar to the variation of observed data around the mean (Table I; Fig. 2).

\section{METABOLIC INDICES}

Temperature discontinuities in Arrhenius plots were not detected (Fig. 3). The Arrhenius relationship was:

$\ln \mathrm{SMR}=-6.284 *\left(1 / \mathrm{K} \times 10^{3}\right)+25.085\left(\mathrm{r}^{2}=0.98\right)$

From the slope of this linear model, the Ea was estimated as $52.25 \mathrm{~kJ} \mathrm{~mol}^{-1}$. The $\mathrm{Q}_{10}$ values for the predicted $\mathrm{HE}_{\mathrm{f}}$ for $1.0 \mathrm{~kg}$ fish, decreased as function of temperature: 2.41 for 19 to $23{ }^{\circ} \mathrm{C} ; 2.12$ for 23 to $26{ }^{\circ} \mathrm{C} ; 1.95$ for 26 to $29{ }^{\circ} \mathrm{C} ; 1.81$ for 29 to $33^{\circ} \mathrm{C}$. The overall $\mathrm{Q}_{10}$ value $\left(19\right.$ to $\left.33^{\circ} \mathrm{C}\right)$ was 2.06 .

\section{DISCUSSION}

The mass-specific SMR increased with increasing water temperature, but decreased as function of body
TABLE I

Parameter estimates \pm S.E. and evaluation of three models (weight schemes) to predict pacu's $\mathrm{HE}_{\mathrm{f}}$ as function of body mass and water temperatures.

\begin{tabular}{|c|c|c|c|}
\hline & \multicolumn{3}{|c|}{ Weighting scheme } \\
\hline & LS* & $(1 / Y)$ & $\left(1 / Y^{2}\right)$ \\
\hline \multicolumn{4}{|l|}{$\begin{array}{l}\text { Parameter } \\
\text { estimates }\end{array}$} \\
\hline $\mathrm{a}$ & $\begin{array}{c}0.0814 \pm \\
0.0238\end{array}$ & $\begin{array}{c}0.0658 \pm \\
0.0203\end{array}$ & $\begin{array}{c}0.0464 \pm \\
0.0148\end{array}$ \\
\hline $\mathrm{b}$ & $\begin{array}{c}0.7059 \pm \\
0.0291\end{array}$ & $\begin{array}{c}0.7578 \pm \\
0.0242\end{array}$ & $\begin{array}{c}0.7882 \pm \\
0.0177\end{array}$ \\
\hline $\mathrm{c}$ & $\begin{array}{c}1.6573 \pm \\
0.0882\end{array}$ & $\begin{array}{c}1.7280 \pm \\
0.0939\end{array}$ & $\begin{array}{c}1.8374 \pm \\
0.0985\end{array}$ \\
\hline \multicolumn{4}{|l|}{$\begin{array}{c}\text { Model } \\
\text { evaluation }\end{array}$} \\
\hline RMSEP & 1.287 & 1.318 & 1.373 \\
\hline RMSEP (\%) & 16.144 & 16.533 & 17.232 \\
\hline $\operatorname{ECT}(\%)^{\mathrm{a}}$ & 0.103 & 2.077 & 5.933 \\
\hline $\operatorname{ER}(\%)^{\mathrm{a}}$ & 0.306 & 0.149 & 1.389 \\
\hline $\operatorname{ED}(\%)^{\mathrm{a}}$ & 99.591 & 97.774 & 92.678 \\
\hline $\mathrm{CD}$ & 1.108 & 1.053 & 1.004 \\
\hline
\end{tabular}

Root of mean square error prediction (RMSEP); RMSEP as percent of observed mean $[\operatorname{RMSEP}(\%)]$; ${ }^{a} \mathrm{MSEP}$ was decomposed into: error due to overall bias of prediction (ECT), error (ER) caused by deviation of the regression slope from unity and error caused by random variation (ED); coefficient of model determination (CD).

*Least squares.

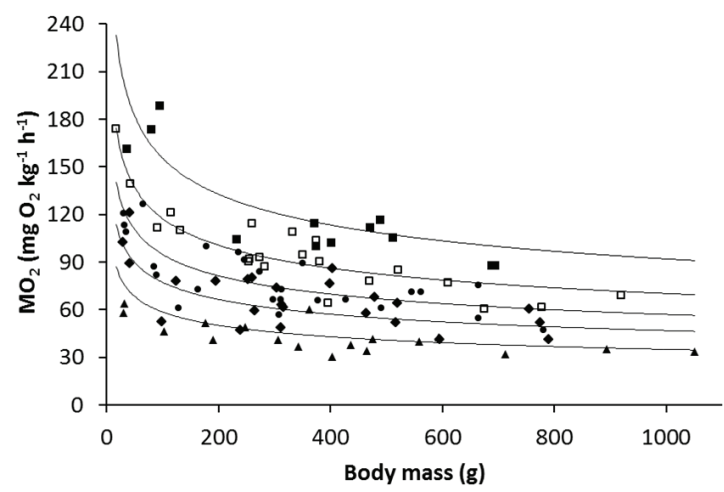

Figure 1 - Specific standard metabolic rate (SMR) of pacu as function of body mass $(\mathrm{M})$ and water temperature $(\mathrm{T})$. Temperatures: $19{ }^{\circ} \mathrm{C}(\boldsymbol{\Delta}), 23{ }^{\circ} \mathrm{C}(\bullet), 26{ }^{\circ} \mathrm{C}(\bullet), 29^{\circ} \mathrm{C}(\square)$ and $33^{\circ} \mathrm{C}(\mathbf{\square})$. Fitted model: $\mathrm{SMR}=42.765 \times \mathrm{M}^{-0.22312} \times \mathrm{e}^{(0.0702 \times T)}\left(\mathrm{r}^{2}\right.$ $=0.84, \mathrm{n}=103)$. 


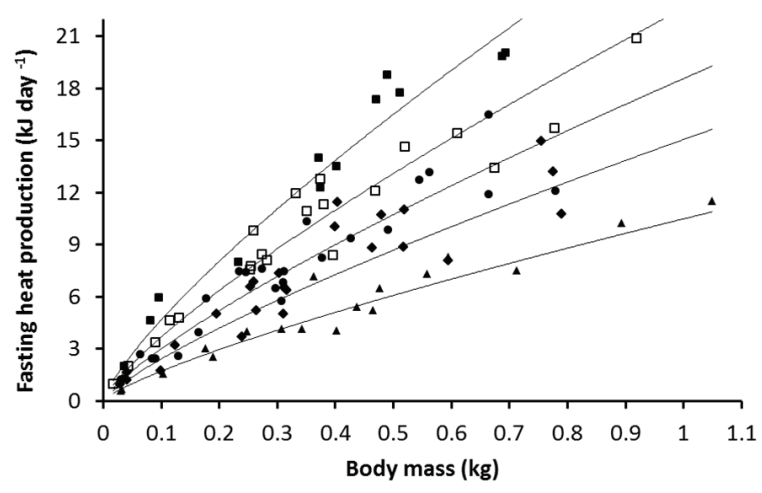

Figure 2 - Fasting heat production $\mathrm{HE}_{\mathrm{f}}$ of pacu as function of body mass (W) and water temperature (T). Temperatures: 19 ${ }^{\circ} \mathrm{C}(\boldsymbol{\Delta}), 23{ }^{\circ} \mathrm{C}(\bullet), 26{ }^{\circ} \mathrm{C}(\bullet), 29^{\circ} \mathrm{C}(\square)$ and $33{ }^{\circ} \mathrm{C}(\bullet)$. Fitted model: $\mathrm{HE}_{\mathrm{f}}=0.04643 \times \mathrm{W}^{0.7882} \times \mathrm{T}^{1.837}(\mathrm{n}=103)$.

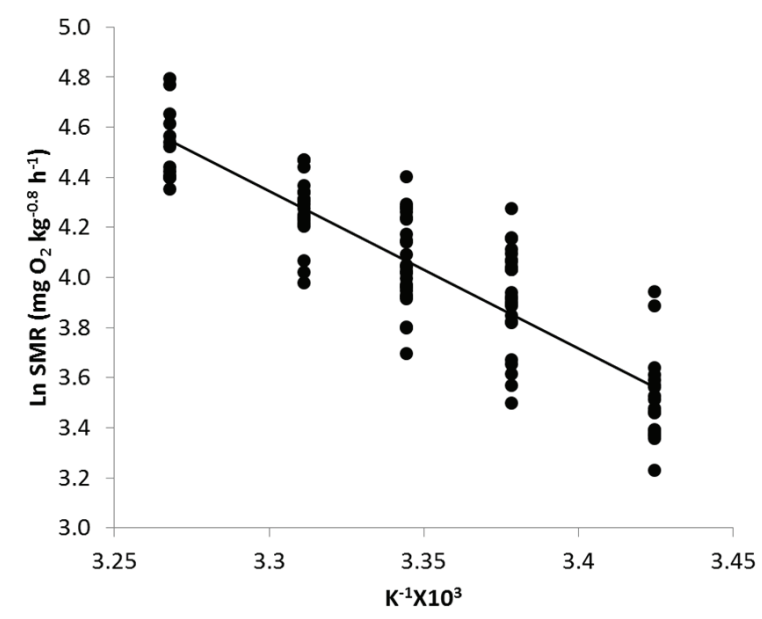

Figure 3 - Arrhenius plot for pacu, where $\mathrm{K}=$ absolute temperature.

$\ln \mathrm{SMR}=-6.284 \times\left(1 / \mathrm{K} \times 10^{3}\right)+25.085\left(\mathrm{r}^{2}=0.98\right)$.

mass, a common trend in fish as actually reported for the bull trout Salvelinus confluentus (Mesa et al. 2013) and barramundi Lates calcarifer (Glencross and Felsing 2006). Two candidate theories may explain the ontogenic declines in mass-specific SMR: (i) the occurrence of an allometric decrease in respiration surface area (gills) relative to body mass; and (ii) the occurrence of an allometric decline in the relative mass and oxygen demand of metabolically active organs and tissues (Post and Lee 1996, Rosenfeld et al. 2015).
The second theory offers a better explanation, that is, most essential tissues to animal life (e.g. brain and visceral organs) have a higher metabolic rate than tissues that are less essential to animal life (e.g. white muscle and fat). The relative size of the most-essential tissues is larger at earlier stages and then decreases with growth, whereas the relative size of tissues that are less essential to life is smaller at earlier stages ant then enlarges with growth (Oikawa and Itazawa 2003).

Estimating the allometric exponent has long been particularly relevant for biological modelling. Analyzing grouped data from 69 teleost fish, Winberg (1956), who published an average value for the mass exponent: $b=0.81$ of the metabolism with the data of several fish, and Clarke and Johnston (1999), who found an average allometric exponent $\mathrm{b}=0.79 \pm 0.11( \pm$ S.E. $)$, argued that the variations could be associated with evolutionary features and statistical biases or methods. Therefore, fitting a linear curve to logarithmic transformations of the original, bivariate data, or fitting a two-parameter power function by iterative, non-linear regression (Packard 2014, Mascaro et al. 2014) is nothing but debatable, at best.

The allometric exponent was herein estimated by non-linear regression and different weighted schemes were considered, the $\left(1 / \mathrm{Y}^{2}\right)$ scheme yielding the lowest standard error of the parameter estimate. Results of the meta-data analysis of Hui and Jackson (2007) allowed inferring that, when detected, heterocedasticity could be reduced by weighted nonlinear regression analysis. Bioenergetics modelling for farmed fish yields a modal allometric exponent of 0.8 (Lupatsch et al. 2003, Booth et al. 2010, Schrama et al. 2012, Grisdale-Helland et al. 2013). The confidence interval registered for the estimated allometric exponent of pacu was 0.753 to 0.823 , and did not differ from the modal value $(\mathrm{p}<0.05)$.

The predicted $\mathrm{HE}_{\mathrm{f}}$ for $1.0-\mathrm{kg}$ fish at 19 and 33 ${ }^{\circ} \mathrm{C}$ was $\mathrm{Q}_{10}=2.06$. This value was lower than that 
reported by Clarke and Johnston (1999) as average value registered for 14 fish species. Same as for the Arrhenius relationship, the Ea for pacu was $52.25 \mathrm{~kJ} \mathrm{~mol}^{-1}$, and larger than that recorded for the mulloway (Argyrosomus japonicas) - $47.6 \mathrm{~kJ} \mathrm{~mol}^{-1}$ - and for the yellowtail kingfish (Seriola lalandi) $44.1 \mathrm{~kJ} \mathrm{~mol}^{-1}$ (Pirozzi and Booth 2009). Both $\mathrm{Q}_{10}$ and Ea values show that pacu has a comparatively lower thermal sensibility.

$$
\text { A model } \mathrm{HE}_{\mathrm{f}}=(-1.04+3.26 \mathrm{~T}-0.05 \mathrm{~T}) * \mathrm{~W}^{0.824}
$$

was fitted for trout by Cho and Bureau (1998), weight (W) measured in $\mathrm{kg}$ and temperature (T) measured in ${ }^{\circ} \mathrm{C}$; therefore, the predicted values for $1.0-\mathrm{kg} \mathrm{kg}$ trout at 5 and $16{ }^{\circ} \mathrm{C}$ are, respectively, $14.01 \mathrm{~kJ} \mathrm{~d}^{-1}$ and $38,32 \mathrm{kjJ} \mathrm{d}^{-1}$. The predicted value for pacu at $19{ }^{\circ} \mathrm{C}$ was $10.38 \mathrm{~kJ} \mathrm{~d}^{-1}$ and the predicted value estimated by the model suggested for Asian sea bass by Glencross (2008) was 15.74 at $19{ }^{\circ} \mathrm{C}$. It comes thus evident that the effect of temperature on $\mathrm{HE}_{\mathrm{f}}$ across tropical and temperate fish is not a constant (Fig. 4). Actually, Clarke and Johnston (1999) suggested that evolutionary adaptations have reduced the overall thermal sensitivity of resting metabolism across species, a phenomenon that can be associated with temperature-dependent compensatory shifts in enzymatic function (Somero 2004).

Another aspect associated with the daily energetic cost of post-absorptive metabolism is the voluntary activity, by its turn associated with feeding behavior and swimming mode. For instance, yellowtail kingfish is a highly active, predatory teleost, with carangiform swimming mode bearing morphological, tuna fish-like adaptations, including a fusiform body shape to reduce drag, fin grooves to increase streamlining, a high aspect-ratio tail with a narrow caudal peduncle, and finlets along the trailing edges of the body. Accordingly, yellowtail kingfish has by high standard metabolic rates (Clark and Seymour 2006). As a matter of fact, Pirozzi and Booth (2009) report that the daily post-absorptive, routine

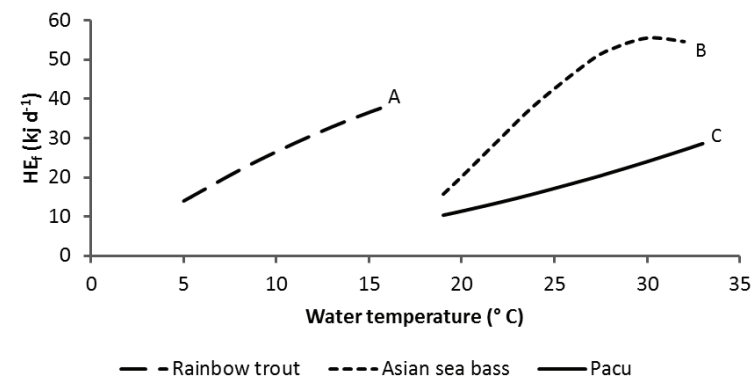

Figure 4 - Comparative, predicted fasting heat losses for 1-0 $\mathrm{kg}$ fish of three fish species: (A) rainbow trout, Oncorhynchus mykiss (Cho and Bureau 1998); (B), Asian sea bass, Lates calcarifer (Glencross 2008) and (C) pacu, Piaractus mesopotamicus.

metabolism $\left(\mathrm{kJ} \mathrm{kg}^{-0.8}\right.$ day $\left.^{-1}\right)$ of yellowtail kingfish as function of temperature can be expressed as a function of the form: $4.041 * \mathrm{~T}-13.14\left(\mathrm{r}^{2}=0.95\right)$, consequently at $27^{\circ} \mathrm{C}$ the energy cost is $95.97 \mathrm{~kJ}$ $\mathrm{kg}^{-0.8}$ day $^{-1}$. On the other hand, pacu is a sedentary, omnivore, laterally compressed, disk shaped fish (Milstein et al. 2000). From the fitted model in the current study the energy cost for post-absorptive, routine metabolism of pacu at $27^{\circ} \mathrm{C}$ is $19.81 \mathrm{~kJ}$ $\mathrm{kg}^{-0.78}$ day $^{-1}$, that is, even taking into account methodological differences between studies, pacu has a lower post-absorptive metabolism cost.

The allometric exponent for scaling pacu's $\mathrm{HE}_{\mathrm{f}}$ neared 0.8 , and lied within the expected range for farmed fish; the thermal sensibility of pacu's $\mathrm{HE}_{\mathrm{f}}$ was lower than that registered for many species. These findings are a sensible advance in the understanding of the ecophysiology and energetic metabolism of pacu, with implications for the farming and husbandry of the species. The fitted model to predict $\mathrm{HE}_{\mathrm{f}}$ can be safely used as basis for bioenergetical models for the species.

\section{ACKNOWLEDGMENTS}

Authors are indebted to Fundação de Amparo à Pesquisa do Estado de São Paulo (FAPESP) for the support to the research project (grant \# 
2012/21937-8) and scholarship granted to TMPC (process \# 2014/15618-2). FAA is an international scholar of Coordenação de Aperfeiçoamento de Pessoal de Nível Superior (CAPES). GBM hold research scholarship from Conselho Nacional de Desenvolvimento Científico e Tecnológico (CNPq).

\section{REFERENCES}

BIBBY J AND TOUTENBURG H. 1977. Prediction and Improved Estimation in Linear Models. J Wiley \& Sons, Berlin, Germany.

BONATE PL. 2011. Pharmacokinetic Pharmacodynamic Modeling and Simulation. $2^{\text {nd }}$ ed., Springer, New York, USA.

BOOTH MA, ALLAN GL AND PIROZZI I. 2010. Estimation of digestible protein and energy requirements of yellowtail kingfish Seriola lalandi using a factorial approach. Aquaculture 307: 247-259.

CHO CY AND BUREAU DP. 1998. Development of bionergetic models and the Fish-PrFEQ software to estimate production, feeding ration and waste output in aquaculture. Aquatic Living Resour 11: 199-210.

CLARK TD AND SEYMOUR RS. 2006. Cardiorespiratory physiology and swimming energetics of a high-energydemand teleost, the yellowtail kingfish (Seriola laland). J Exp Bio 209: 3940-3951.

CLARKE A AND JOHNSTON M. 1999. Scaling of metabolic rate with body mass and temperature fish in teleost fish. J Anim Ecol 68: 893-905.

ELLIOTT JM AND DAVIDSON W. 1975. Energy equivalents of oxygen consumption in animal energetics. Oecologia 19: 195-201.

GLENCROSS BD. 2008. A factorial growth and feed utilization model for barramundi, Lates calcarifer based on Australian production conditions. Aquacult Nutr 14: 360-373.

GLENCROSS BD AND FELSING M. 2006. Influence of fish size and water temperature on the metabolic demand for oxygen by barramundi, Lates calcarifer, in freshwater. Aquac Res 37: 1055-1062.

GRISDALE-HELLAND B, GATLIN DM AND HELLAND SJ. 2013. Optimization of dietary macronutrients for Atlantic salmon post-smolts using increasing ration levels. Aquaculture 408: 88-94.

HEINEN JM. 1998. Light control for fish tanks. Prog Fish Cult 60: 323-330.

HERRMANN JP AND ENDERS C. 2000. Effect of body size on the standard metabolism of horse mackerel. J Fish Biol 57: 746-760.

HÖLKER F. 2003. The metabolic rate of roach in relation to body size and temperature. J Fish Biol 62: 565-579.
HOULIHAN D, BOUJARD T AND JOBLING M. 2001. Food Intake in Fish. Blackwell Science, Ltd., Oxford, UK.

HUI D AND JACKSON RB. 2007. Uncertainty in scaling exponent estimation: a case study in basal metabolic rate and body mass. J Theor Biol 249: 168-177.

LOAGUE K AND GREEN RE. 1991. Statistical and graphical methods for evaluating solute transport models: Overview and application. J Contam Hydrol 7: 51-73.

LUPATSCH I, KISSIL GW AND SKLAN D. 2003. Comparison of energy and protein efficiency among three fish species: gilthead sea bream (Sparus aurata), European sea bass (Dicentrarchus labrax) and white grouper (Epinephelus aeneus): energy expenditure for protein and lipid deposition. Aquaculture 225: 175-189.

MASCARO J, LITTON CM, HUGHES RF, UOWOLO A AND SCHNITZER SA. 2014. Is logarithmic transformation necessary in allometry? Ten, one-hundred, one-thousand-times yes. Biol J Linn Soc 111: 230-233.

MESA MG, WEILAND LK, CHRISTIANSEN HE, SAUTER ST AND BEAUCHAMP DA. 2013. Development and evaluation of a bioenergetics model for bull trout. T Am Fish Soc 142: 41-49.

MILSTEIN A, ZORAN M, PERETZ Y AND JOSEPH D. 2000. Low temperature tolerance of pacu, Piaractus mesopotamicus. Environ Biol Fish 58: 455-460.

NRC - NATIONAL RESEARCH COUNCIL. 2011. Nutrient Requirements of Fish and Shrimp. National Academy Press, Washington, DC, USA.

OIKAWA S AND ITAZAWA Y. 2003. Relationship between summated tissue respiration and body size in a marine teleost, the porgy Pagrus major. Fish Sci 69: 687-694.

PACKARD GC. 2014. Multiplicative by nature: logarithmic transformation in allometry. J Exp Zool 322: 202-207.

PIROZZI I AND BOOTH M. 2009. The routine metabolic rate of mulloway (Argyrosomus japonicus: Sciaenidae) and yellowtail kingfish (Seriola lalandi: Carangidae) acclimated to six different temperatures. Comp Biochem Phys A 152: 586-592.

POST JR AND LEE JA. 1996. Metabolic ontogeny of teleost fishes. Can J Fish Aquat Sci 53: 910-923.

RITZ C AND STREIBIG JC. 2008. Nonlinear Regression with R. Springer Verlag, New York, NY, USA.

ROCHE DG, BINNING SA, BOSIGER, Y, JOHANSEN JL AND RUMMER JL. 2013. Finding the best estimates of metabolic rates in a coral reef fish. J Exp Biol 216: 2103-2110.

ROSENFELD J, VAN LEEUWEN T, RICHARDS J AND ALLEN D. 2015. Relationship between growth and standard metabolic rate: measurement artefacts and implications for habitat use and life-history adaptation in salmonids. J Anim Ecol 84: 4-20.

SCHRAMA JW, SARAVANAN S, GEURDEN I, HEINSBROEK LTN, KAUSHIK SJ AND VERRETH 
JAJ. 2012. Dietary nutrient composition affects digestible energy utilisation for growth: a study on Nile tilapia (Oreochromis niloticus) and a literature comparison across fish species. Brit J Nutr 108: 277-289.

SOMERO GN. 2004. Adaptation of enzymes to temperature: searching for basic "strategies". Comp Biochem Phys B 139: 321-333.

STEFFENS W. 1989. Principles of Fish Nutrition. Ellis Horwood, Chichester, UK.
STEFFENSEN JF, JOHANSEN K AND BUSHNELL PG. 1984. An automated swimming respirometer. Comp Biochem Phys A 79: 437-440.

SVENDSEN MBS, BUSHNELL PG AND STEFFENSEN JF. 2016. Design and setup of intermittent-low respirometry system for aquatic organisms. J Fish Biol 88: 26-50.

WINBERG GG. 1956. Rate of metabolism and food requirements of fishes. J Fish Res Bd Can Transl Ser 194: 1-202. 